\title{
OPEN The nickel-chelator dimethylglyoxime inhibits human amyloid beta peptide in vitro aggregation
}

\author{
Stéphane L. Benoit ${ }^{1,2}$ \& Robert J. Maier ${ }^{1,2} \bowtie$
}

One of the hallmarks of the most common neurodegenerative disease, Alzheimer's disease (AD), is the extracellular deposition and aggregation of Amyloid Beta (A $\beta$ )-peptides in the brain. Previous studies have shown that select metal ions, most specifically copper (Cu) and zinc ( $\mathrm{Zn}$ ) ions, have a synergistic effect on the aggregation of A $\beta$-peptides. In the present study, inductively coupled plasma mass spectrometry (ICP-MS) was used to determine the metal content of a commercial recombinant human $A \beta_{40}$ peptide. $\mathrm{Cu}$ and $\mathrm{Zn}$ were among the metals detected; unexpectedly, nickel (Ni) was one of the most abundant elements. Using a fluorescence-based assay, we found that $A \beta_{40}$ peptide in vitro aggregation was enhanced by addition of $\mathrm{Zn}^{2+}$ and $\mathrm{Ni}^{2+}$, and $\mathrm{Ni}^{2+}$-induced aggregation was facilitated by acidic conditions. Nickel binding to $A \beta_{40}$ peptide was confirmed by isothermal titration calorimetry. Addition of the $\mathrm{Ni}$-specific chelator dimethylglyoxime (DMG) inhibited $A \beta_{40}$ aggregation in absence of added metal, as well as in presence of $\mathrm{Cu}^{2+}$ and $\mathrm{Ni}^{2+}$, but not in presence of $\mathrm{Zn}^{2+}$. Finally, mass spectrometry analysis revealed that DMG can coordinate $\mathrm{Cu}$ or $\mathrm{Ni}$, but not $\mathrm{Fe}$, Se or $\mathrm{Zn}$. Taken together, our results indicate that $\mathrm{Ni}^{2+}$ ions enhance, whereas nickel chelation inhibits, $\mathrm{A} \beta$ peptide in vitro aggregation. Hence, DMG-mediated Ni-chelation constitutes a promising approach towards inhibiting or slowing down $A \beta_{40}$ aggregation.

Alzheimer's disease $(\mathrm{AD})$, discovered more than a century ago by Lois Alzheimer ${ }^{1}$, is the most common cause of dementia in many elderly people, as well as in individuals with Down syndrome who survive beyond age 50 . AD is a major health problem, in the United States and the rest of the world. According to the most recent national vital statistics report available in the USA (year 2017), AD is estimated to be the fifth cause of death for people aged 65 and over, and the third cause of death for people aged 85 and over, behind heart disease and cancer ${ }^{2}$. In the absence of a cure, and because of the overall aging population, a study from the Alzheimer's Association predicts that by mid-century 13.8 million Americans will live with the disease, with one new case of AD developing every $33 \mathrm{~s}$, resulting in nearly 1 million new cases per year. Based on the time of onset, AD is classified into two types: early-onset AD (EOAD), which typically develops before the age of 65, and late-onset AD (LOAD) for those older than $65^{3}$. In addition to intraneuronal tangles of hyperphosphorylated tau $(\tau)$ protein ${ }^{4}$, one hallmark of $\mathrm{AD}$ is characterized by various pathological markers in the brain, including accumulation of Amyloid Beta $(\mathrm{A} \beta)$ protein (in the form of senile plaques), as first proposed by Hardy and Higgins in a landmark study known as "the amyloid beta cascade hypothesis" . Sequential proteolysis of the amyloid precursor protein (APP), an ancient and highly conserved protein ${ }^{6}$, by $\beta$-secretase and $\gamma$-secretase enzymes yields $A \beta$ peptides of various lengths (38, 40 or 42 amino acids), depending upon the exact site of cleavage by the $\gamma$-secretase 7 . While the most abundant $A \beta$ peptide is $A \beta_{40}$, the most toxic is $A \beta_{42}{ }^{8}$. The release of $A \beta$ peptides is a normal physiological process. Indeed, not only $A \beta$ peptides are naturally present in both the brain and the cerebrospinal fluid throughout the life of an individual ${ }^{9-11}$, they are also produced by cultured cells during normal metabolism ${ }^{12}$. However, once $A \beta$ peptides form filamentous aggregates (e.g., amyloids), not only can they propagate their abnormal structures to the same precursor molecules (seeding), they can also propagate to other protein monomers (cross-seeding), such as that involved in Parkinson's or Type 2 diabetes diseases ${ }^{13}$.

Alzheimer's disease occurs sporadically in most cases; however, a sizable number of cases can be linked to mutations in various genes. For instance, mutations in the APP gene, or in genes encoding for enzymes involved

${ }^{1}$ Department of Microbiology, The University of Georgia, 805 Biological Sciences Bldg, Athens, GA 30602, USA. ${ }^{2}$ Center for Metalloenzyme Studies, The University of Georgia, Athens, GA 30602, USA. ${ }^{\square}$ email: rmaier@ uga.edu 
in the APP processing (e.g. PSEN1 or PSEN2), are predominantly associated with EOAD, whereas mutations in genes encoding for enzymes related to $\mathrm{A} \beta$ turnover, such as the apolipoprotein $\mathrm{E}$ (e.g. APOE), are usually associated with $\mathrm{LOAD}^{14,15}$. Besides genetic factors, environmental factors have been shown to play a role in $\mathrm{AD}$, as revealed by a study on twins ${ }^{16}$. Environmental factors include toxic gases, such as $\mathrm{CO}, \mathrm{CO}_{2}, \mathrm{SO}_{2}$ and $\mathrm{NO}_{2}{ }^{17}$, or metals, several of which have been shown to play a role on $\mathrm{A} \beta$ aggregation, fibrillization and toxicity, with potential implications on the progression of AD (for a recent review, see Liu et al.) ${ }^{18}$. The list includes heavy metals, such as aluminum $(\mathrm{Al})^{19}$, cadmium $(\mathrm{Cd})^{20}$ and mercury $(\mathrm{Hg})^{21,22}$, and essential metals, such as copper $(\mathrm{Cu})$ and zinc $(\mathrm{Zn})$, and, to a lesser extent, iron $(\mathrm{Fe})^{23}$. The role of $\mathrm{Cu}(\mathrm{I}), \mathrm{Cu}(\mathrm{II})$, or $\mathrm{Zn}(\mathrm{II})$ has been well documented ${ }^{24-26}$. Firstly, both $\mathrm{A} \beta_{40}$ and $\mathrm{A} \beta_{42}$ peptides have been shown to bind $\mathrm{Cu}(\mathrm{II})$ or $\mathrm{Zn}$ (II) with significant affinity in vitro, leading to $A \beta$ aggregation ${ }^{19,27-30}$; secondly, a similar effect was observed in vivo, leading to plaque build-up and toxicity in $\mathrm{AD}$ animal models, for instance with $\mathrm{Cu}(\mathrm{II})$ in rabbits ${ }^{31}$, or with $\mathrm{Zn}$ (II) in mice ${ }^{32}$; thirdly, post-mortem analysis revealed that respective $\mathrm{Cu}, \mathrm{Fe}$ and $\mathrm{Zn}$ levels in plaques of $\mathrm{AD}$ brains were 5.7, 2.8, and 3.1-fold higher compared to normal brains ${ }^{33}$; fourthly, accumulation of $\mathrm{Cu}$ and $\mathrm{Zn}$ co-localized with $\mathrm{A} \beta$ peptide deposits ${ }^{34}$. Taken together, these results have given birth to a theory known as the "metal hypothesis of AD", that links metal homeostasis (especially that of $\mathrm{Cu}, \mathrm{Fe}$ and $\mathrm{Zn}$ ) and $\mathrm{AD}^{35}$. Recent discoveries on $\mathrm{A} \beta$ peptides-lipid interactions have confirmed the importance of metals in the onset and progression of $\mathrm{AD}$ : A $\beta$ peptides can associate with cellular membranes, and $\mathrm{A} \beta$-bound metals (especially $\mathrm{Zn}$ and $\mathrm{Al}$ ) can blockade and disrupt $\mathrm{Ca}^{2+}$ channels, leading to neurotoxicity.

The logical follow up to these observations was the use of chelators to inhibit $\mathrm{A} \beta$ peptide aggregation, with the long-term goal of using metal chelation as therapeutic strategy for $\mathrm{AD}^{36}$. This research avenue has been investigated by several groups, with mixed outcomes. Chelators, such as EGTA, "tpen" ( $N, N, N^{\prime}, N^{\prime}$-tetrakis(2-pyridylmethyl) ethylene diamine), and bathocuproine have been shown to solubilize A $\beta$ plaques from post-mortem brain tissue ${ }^{37}$. The 8-hydroxyquinoline derivatives Clioquinol and BPT-2, two copper-zinc chelators, have shown promising results in vitro ${ }^{35,38}$. Being able to cross the blood-brain-barrier (BBB), both have been tested in clinical trials, unfortunately the results appear inconclusive ${ }^{39}$. In another unrelated clinical trial, the rate of decline of daily living skills was significantly reduced in $\mathrm{AD}$ patients given desferrioxamine intramuscular twice daily for two years ${ }^{40}$. The authors originally attributed this effect to aluminum chelation, however desferrioxamine binds preferentially to iron (also copper and zinc, albeit with lower affinity); hence it is hard to draw firm conclusions about this trial. Alternative ways to target and modulate the toxicity of metal-bound (or metal-free) A $\beta$ species include the use of (i) glycosylated polyphenols and their esterified derivatives, which present the advantage of using natural low toxicity compounds ${ }^{41}$; (ii) synthetic flavonoids and amino-isoflavones, which have shown promising results towards targeting metal sites ${ }^{42}$; (iii) small molecules, such as $N^{1}, N^{1}$-dimethyl- $N^{4}$-(pyridin-2ylmethyl)benzene-1,4-diamine ("L2-b") and its derivatives ${ }^{43,44}$; (iv) $\beta$-sheet breakers, which are small peptides (five amino-acids long) effective in reducing the $\mathrm{A} \beta_{1-40}$ aggregation, even in the presence of metal ions ${ }^{45}$.

In contrast to $\mathrm{Cu}, \mathrm{Fe}$ and $\mathrm{Zn}$, which are required cofactors for hundreds of enzymes, and fairly abundant in animals and humans ${ }^{46}$, nickel (Ni) does not appear to be needed in mammals, as mammalian hosts do not contain known Ni-dependent enzymes ${ }^{47}$. Furthermore, Ni levels are low, with less than 5 ppm ( $\mu \mathrm{g} / \mathrm{g}$ of ash) in most human organs, corresponding to less than $1 \%$ of the amount of $\mathrm{Zn}$ measured in the brain, heart, lung, or muscle, and less than $0.1 \%$ of the amount of $\mathrm{Zn}$ in the liver and kidney ${ }^{48}$. Even though $\mathrm{Ni}$ is rarely mentioned in association with $\mathrm{A} \beta$ peptides, a potential role for this transition metal should not be discarded. For instance, levels of $\mathrm{A} \beta_{40}$ and $\mathrm{A} \beta_{42}$ peptides were significantly increased (72-129\%) in brains of mice exposed to a Ni-nanoparticle model of air pollution ${ }^{49}$, suggesting Ni might play a role in $\beta$-amyloid aggregation, at least in mice ${ }^{49}$. This finding prompted us to investigate the role of $\mathrm{Ni}$ in $\mathrm{A} \beta$ peptide aggregation, as well as the potential benefit of using the $\mathrm{Ni}$ chelator dimethylglyoxime (DMG) to slow down or even inhibit aggregation.

\section{Results}

Commercial recombinant $A B_{40}$ peptide contains metals, including copper, zinc, and nickel. Most $\mathrm{A} \beta$ peptide preparations used for in vitro aggregation studies are synthetic (e.g. chemically synthesized) or recombinant peptides (e.g. expressed in prokaryotic or eukaryotic organisms). To determine what type of metals is associated with commercial human recombinant $\mathrm{A} \beta$ peptide, a $\mathrm{A} \beta_{40}$ peptide preparation was subjected to a twenty-element ICP-MS analysis (Table 1). Aluminum, copper, manganese and zinc were among the metals found in the $\mathrm{A} \beta_{40}$ peptide preparation, whereas iron was not detected. Surprisingly, the most abundant element associated with the recombinant $\mathrm{A} \beta_{40}$ peptide was selenium, followed by nickel ( $1 \mathrm{mg}$ of $\mathrm{Ni}$ per $\mathrm{g}$ of $\mathrm{A} \beta_{40}$ peptide, corresponding to 0.073 moles of Ni per mole of peptide). Taken together, these results suggest that the recombinant $\mathrm{A} \beta_{40}$ peptide used in this study is already metal-bound upon commercialization; metals may be acquired during bacterial expression in the host (E. coli), during the purification process, or both. To our knowledge, it is the first time nickel is found in a commercial recombinant $\mathrm{A} \beta_{40}$ peptide purified preparation, suggesting the peptide (or aggregated peptides) can naturally coordinate the transition metal nickel, in addition to other metals such as aluminum, copper, manganese, selenium and zinc. The metal content of all the other kit components, including TBS, thioflavin and $\mathrm{NaOH}$ (used to resuspend the peptide) was also analyzed by ICP-MS (Table S1). Aluminum, manganese, iron, nickel copper, and zinc were detected in these components, however no selenium was detected. Besides, the bulk of nickel in the assay (reaction mix) was brought by the peptide (>22-fold more $\mathrm{Ni}$ in $\mathrm{A} \beta_{40}$ compared to other kit components, see Table S1).

Addition of nickel enhances $A B_{40}$ peptide aggregation. To determine the effect of nickel on $A \beta_{40}$ peptide aggregation, a thioflavin-(ThT)-based aggregation kit was used in absence or presence of supplemental $\mathrm{Ni}(\mathrm{II})$ (Fig. 1 and Table 2). In absence of supplemental metal, a moderate but steady increase in $\mathrm{A} \beta_{40}$ peptide aggregation was observed (average fluorescence rate of $152 \mathrm{RFU} / \mathrm{min}$, Fig. 1). We hypothesized this might be due 


\begin{tabular}{|c|c|c|}
\hline \multirow[b]{2}{*}{ Element } & \multicolumn{2}{|l|}{ Metal/A $\beta 40$ ratio } \\
\hline & $\mu \mathrm{g}$ metal per g of $\mathrm{A} \beta_{40}$ peptide $^{\mathrm{a}}$ & mmole metal per mole of $A \beta_{40}$ peptide \\
\hline Lithium $\left({ }^{7} \mathrm{Li}\right)$ & ND & $\mathrm{ND}$ \\
\hline Beryllium $\left({ }^{9} \mathrm{Be}\right)$ & ND & ND \\
\hline Aluminum $\left({ }^{27} \mathrm{Al}\right)$ & 65.7 & 10.5 \\
\hline Vanadium $\left({ }^{51} \mathrm{~V}\right)$ & 1.03 & 0.09 \\
\hline Chromium $\left({ }^{52} \mathrm{Cr}\right)$ & 15 & 1.25 \\
\hline Manganese $\left({ }^{55} \mathrm{Mn}\right)$ & 1.06 & 0.08 \\
\hline Iron $\left({ }^{56} \mathrm{Fe}\right)$ & ND & ND \\
\hline Cobalt $\left({ }^{59} \mathrm{Co}\right)$ & ND & ND \\
\hline Nickel $\left({ }^{60} \mathrm{Ni}\right)$ & 1,005 & 72.5 \\
\hline Copper $\left({ }^{65} \mathrm{Cu}\right)$ & 22.8 & 1.55 \\
\hline Zinc $\left({ }^{66} \mathrm{Zn}\right)$ & 45.7 & 3.07 \\
\hline Arsenic $\left({ }^{75} \mathrm{As}\right)$ & ND & ND \\
\hline Selenium $\left({ }^{82} \mathrm{Se}\right)$ & 27,784 & 1470 \\
\hline Rubidium $\left({ }^{85} \mathrm{Rb}\right)$ & ND & ND \\
\hline Strontium $\left({ }^{88} \mathrm{Sr}\right)$ & 3.6 & 0.18 \\
\hline Cadmium $\left({ }^{111} \mathrm{Cd}\right)$ & ND & ND \\
\hline Cesium $\left({ }^{133} \mathrm{Cs}\right)$ & ND & ND \\
\hline Barium $\left({ }^{137} \mathrm{Ba}\right)$ & 32.5 & 1.03 \\
\hline Lead $\left({ }^{207} \mathrm{~Pb}\right)$ & 0.25 & 0.005 \\
\hline Uranium $\left({ }^{238} \mathrm{U}\right)$ & ND & ND \\
\hline
\end{tabular}

Table 1. ICP-MS metal analysis of commercial recombinant $\mathrm{A} \beta_{40}$-peptide. $N D$ not detected (below detection

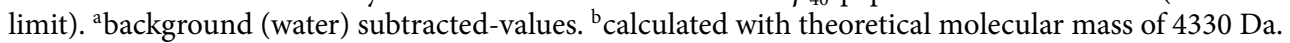

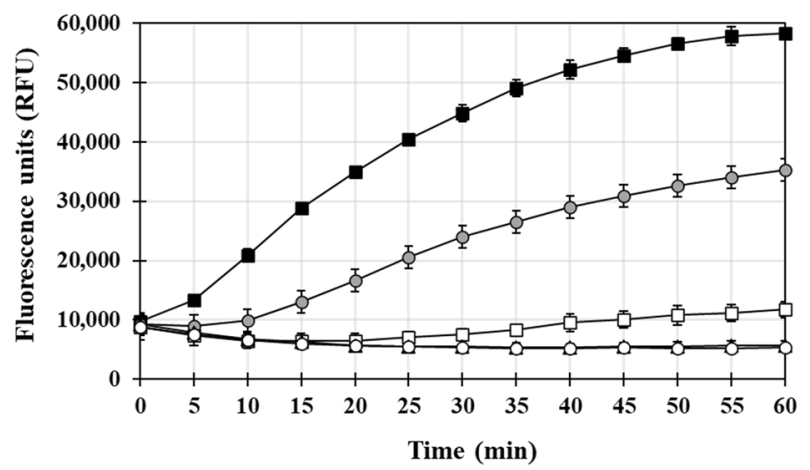

Figure 1. Time-dependent $\mathrm{A} \beta_{40}$ peptide aggregation in absence or presence of Ni(II) and DMG. $\mathrm{A} \beta_{40}$ peptide $(40 \mu \mathrm{M})$ and thioflavin $(40 \mu \mathrm{M})$ were mixed: in the absence of $\mathrm{Ni}(\mathrm{II})$ and DMG (white squares); with $100 \mu \mathrm{M}$ $\mathrm{Ni}(\mathrm{II})$ (black squares); with $100 \mu \mathrm{M} \mathrm{Ni}(\mathrm{II})$ and $100 \mu \mathrm{M}$ DMG (grey circles); with $100 \mu \mathrm{M} \mathrm{Ni(II)}$ and $500 \mu \mathrm{M}$ DMG (black triangles); with $100 \mu \mathrm{M} \mathrm{Ni(II)}$ and $1 \mathrm{mM}$ DMG (white circles). ThT-based fluorescence was measured every $5 \mathrm{~min}$ for $60 \mathrm{~min}$. A ThT-only background control (no A $\beta_{40}$ peptide) was included in the assay (data not shown). Results shown for each time point represent the mean and standard deviation (error bars) of background-subtracted values for triplicate wells. Results shown here correspond to results of experiment B, Table 2 .

to the intrinsic presence of metallic ions, including $\mathrm{Cu}^{2+}, \mathrm{Ni}^{2+}$ and $\mathrm{Zn}^{2+}$, as revealed by the ICP-MS metal analysis conducted in the present study (see above). Addition of $10 \mu \mathrm{M} \mathrm{NiSO}_{4}$ to the mixture increased the average aggregation rate by 2.5 -fold (Table 1), while addition of $100 \mu \mathrm{M} \mathrm{NiSO}_{4}$ resulted in a dramatic 5.7-fold increase compared to the no supplemental metal control, suggesting the divalent cation $\mathrm{Ni}^{2+}$ can bind to the $\mathrm{A} \beta_{40}$ peptide and enhance its aggregation (Fig. 1 and Table 2). A similar effect was observed when $\mathrm{NiCl}_{2}$ was used (instead of $\mathrm{NiSO}_{4}$ ) as source of $\mathrm{Ni}^{2+}$ (data not shown); hence, the nature of the counterion does not appear to play a role in (or interfere with) the observed aggregation. Upon addition of 10 and $100 \mu \mathrm{M} \mathrm{Zn(II),} \mathrm{a} \mathrm{fivefold} \mathrm{and} \mathrm{14-fold}$ increase in $\mathrm{A} \beta_{40}$ peptide aggregation rate was observed compared to the control, respectively (Table 2), in agreement with previously published studies ${ }^{27-29}$; in contrast, addition of 10 or $100 \mu \mathrm{M} \mathrm{CuSO}$ had no significant effect on the aggregation rate (Table 2). This result (lack of aggregation) could be due to the $\mathrm{pH}$ used in our study 


\begin{tabular}{|c|c|c|c|c|}
\hline \multirow[b]{2}{*}{ Supplemental metal $(\mu \mathrm{M})$} & \multicolumn{4}{|c|}{ Supplemental DMG $(\mu \mathrm{M})$} \\
\hline & 0 & 100 & 500 & 1000 \\
\hline \multicolumn{5}{|c|}{ Relative $\mathbf{A} \beta 40$ aggregation rate (\% control) } \\
\hline \multicolumn{5}{|c|}{ A } \\
\hline None (0) & 100 & $33 \pm 2$ & ND & $\mathrm{ND}$ \\
\hline $\mathrm{Ni}(10)$ & $252 \pm 8$ & $58 \pm 11$ & ND & ND \\
\hline $\mathrm{Zn}(10)$ & $505 \pm 29$ & $457 \pm 39$ & ND & ND \\
\hline $\mathrm{Cu}(10)$ & $103 \pm 19$ & $54 \pm 12$ & ND & ND \\
\hline \multicolumn{5}{|l|}{$\mathrm{B}$} \\
\hline None (0) & 100 & $15 \pm 14$ & $<1$ & $<1$ \\
\hline $\mathrm{Ni}(100)$ & $567 \pm 61$ & $410 \pm 91$ & $<1$ & $<1$ \\
\hline $\mathrm{Zn}(100)$ & $1423 \pm 258$ & $1468 \pm 56$ & $833 \pm 156$ & $328 \pm 63$ \\
\hline \multicolumn{5}{|l|}{$\mathrm{C}$} \\
\hline None (0) & 100 & $48 \pm 8$ & $15 \pm 5$ & $21 \pm 10$ \\
\hline $\mathrm{Cu}(100)$ & $77 \pm 2$ & $66 \pm 15$ & $49 \pm 8$ & $40 \pm 3$ \\
\hline
\end{tabular}

Table 2. Recombinant human $\mathrm{A} \beta_{40}$ aggregation rate as a function of DMG and/or metal. Three independent human $\mathrm{A} \beta_{40}$ peptide aggregation assays $(\mathrm{A}, \mathrm{B}, \mathrm{C})$ were performed, with $25 \mu \mathrm{M} \mathrm{A} \beta_{40}$ peptide and $20 \mu \mathrm{M}$ thioflavin (ThT) (A), or $40 \mu \mathrm{M} \mathrm{A} \beta_{40}$ and $40 \mu \mathrm{M}$ ThT (B and C), in absence or presence of DMG $(100,500$ or $1000 \mu \mathrm{M})$ and $\mathrm{Ni}, \mathrm{Zn}, \mathrm{Cu}(10$ or $100 \mu \mathrm{M})$. ThT-based fluorescence (RFU) was measured every 5 min for $60 \mathrm{~min}$ and background fluorescence (ThT alone) was subtracted from all reactions. All reactions were done in triplicate. Results (relative $\mathrm{A} \beta_{40}$ peptide aggregation rate) represent the mean and standard deviation $(\mathrm{n}=3)$ of the ratio (\%) of the maximal aggregation rate (RFU per min) obtained for each indicated (metal, DMG) condition compared to the aggregation rate of the control ( $\mathrm{A} \beta_{40}$ peptide only, no DMG, no metal, set as $100 \%$, in bold). ND, not determined.

( $\mathrm{pH}$ 7.4). Indeed, $\mathrm{Cu}$ has been shown to induce $\mathrm{A} \beta_{40}$ peptide aggregation at acidic $\mathrm{pH}^{30}$, while at neutral $\mathrm{pH}$ it is known to promote mostly soluble dimers ${ }^{50}$.

Addition of DMG inhibits $A \beta_{40}$ peptide aggregation. Addition of $100 \mu \mathrm{M}$ of the Ni-specific chelator DMG in absence of supplemented metal severely reduced $\mathrm{A} \beta_{40}$ peptide aggregation, by 40 to $85 \%$ depending on experiments (Table 2). Furthermore, addition of $500 \mu \mathrm{M}$ or $1000 \mu \mathrm{M}$ DMG led to partial or full inhibition of the aggregation; in the latter case, we measured flat or even decreasing average fluorescence rates (reported as $<1 \%$ of control, Table 2). Hence this dose-dependent inhibitory effect suggests that (i) DMG is able to pull metals away from the $\mathrm{A} \beta_{40}$ peptide and (ii) the $\mathrm{A} \beta_{40}$ peptide aggregation observed in absence of supplemented metals is likely due to the intrinsic presence of metallic ions (including $\mathrm{Ni}^{2+}$ ) within the recombinant peptide preparation, since the addition of the chelator leads to inhibition. When increasing amounts of DMG were added to the reaction mixture in presence of $100 \mu \mathrm{M} \mathrm{Ni}^{2+}, \mathrm{Cu}^{2+}$ or $\mathrm{Zn}^{2+}$, results with mixed outcomes were obtained. Complete inhibition was observed in presence of $\mathrm{Ni}$ (Fig. 1 and Table 2) and only partial inhibition was seen in presence of $\mathrm{Cu}$ or $\mathrm{Zn}$, however $\mathrm{Zn}$ was still able to induce $\mathrm{A} \beta_{40}$ peptide aggregation (Table 2). The respective efficacy (or lack thereof) of DMG in presence of $\mathrm{Cu}, \mathrm{Ni}$ and $\mathrm{Zn}$ correlates with the chelator's respective affinity for each metal, as revealed by mass spectrometry analysis of metal-DMG complexes (see below).

Effect of $\mathrm{pH}$ on $\mathrm{A} \boldsymbol{\beta}_{40}$ peptide aggregation in presence of metals or DMG. To study the effect of $\mathrm{pH}$ on $\mathrm{A} \beta_{40}$ peptide aggregation (in presence of metals or DMG), additional ThT-based aggregation experiments were conducted at $\mathrm{pH} 6.5,7.5$ or 8.5 , with $25 \mu \mathrm{M} \mathrm{A} \beta_{40}$, in absence or presence of $\mathrm{NiSO}_{4}(25 \mu \mathrm{M}), \mathrm{CuSO}_{4}$ $(25 \mu \mathrm{M}), \mathrm{ZnSO}_{4}(10 \mu \mathrm{M})$, or DMG $(100 \mu \mathrm{M})$ (Fig. 2 and data not shown). Overall, aggregation rates at alkaline $\mathrm{pH} 8.5$ (black symbols) were lower compared to $\mathrm{pH} 7.5$ (grey symbols) or $\mathrm{pH} 6.5$ (white symbols). As previously observed, addition of $\mathrm{Zn}$ (II) led to the fastest and sharpest increase in fluorescence (triangles) under all pHs tested. Interestingly, $\mathrm{Ni}(\mathrm{II})$-induced aggregation (squares) was faster at $\mathrm{pH} 6.5$, compared to $\mathrm{pH} 7.5$, while it was absent at $\mathrm{pH} 8.5$ (black squares). $\mathrm{A} \beta_{40}$ peptide aggregation in presence of $\mathrm{Cu}(\mathrm{II})$ or $\mathrm{DMG}$ was negligible under all $3 \mathrm{pH}$ conditions tested (data not shown).

Nickel binding to human recombinant $A \beta_{40}$ peptide is confirmed by isothermal titration calorimetry. Isothermal titration calorimetry (ITC) has been already used to analyze copper or zinc binding to various $\mathrm{A} \beta$ peptides, including $\mathrm{A} \beta_{40}{ }^{51-53}$. In the current study, we used ITC to determine whether nickel can bind to the $\mathrm{A} \beta_{40}$ peptide. The peptide (same used in ThT-based aggregation assays) was present in the sample cell at a concentration of $20 \mu \mathrm{M}$. Twenty injections of $\mathrm{NiSO}_{4}(1 \mathrm{mM}$ solution, $5 \mu \mathrm{M}$ increments in sample cell $)$ were performed every $5 \mathrm{~min}$ under constant stirring $(350 \mathrm{rpm})$ at $25^{\circ} \mathrm{C}$, and the heat release was measured (Fig. 3). The heat release profile indicates Ni binding to the peptide (Fig. 3, top Panel). The best fit of Ni titration (Fig. 3, bottom Panel) suggests an apparent stoichiometry of less than $1 \mathrm{~mol} \mathrm{Ni}(\mathrm{II})$ per mole of $\mathrm{A} \beta_{40}$ peptide $(\sim 0.7)$, in range with previously reported stoichiometry ratios of $1: 1$ for $\mathrm{Cu}(\mathrm{II})$ or $\mathrm{Zn}(\mathrm{II})$, and $\mathrm{A} \beta_{40}{ }^{54}$. The apparent $\mathrm{K}_{\mathrm{d}}$ value for $\mathrm{Ni}$ is approximately $4.2 \mu \mathrm{M}$, similar to that previously reported of $7 \pm 3 \mu \mathrm{M}$ for $\mathrm{Zn}^{53}$. Furthermore, the 


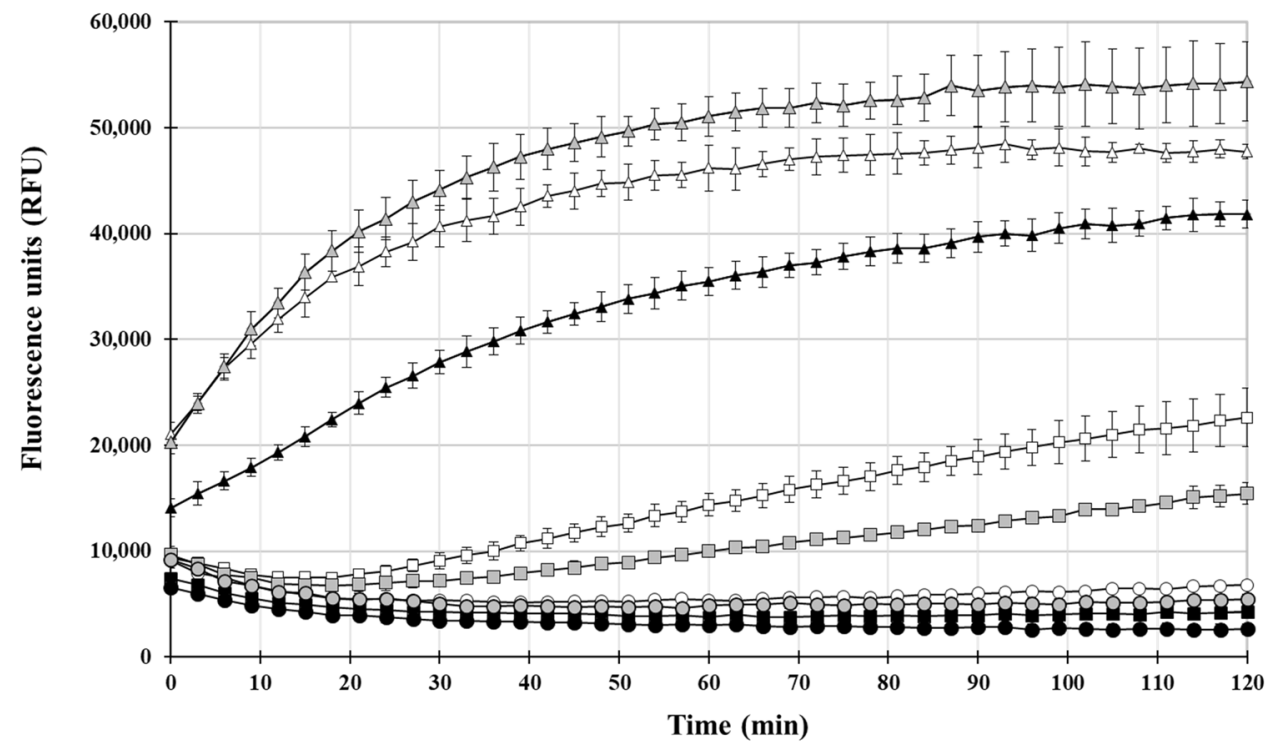

Figure 2. Time-dependent $\mathrm{A} \beta_{40}$ peptide aggregation in absence or presence of $\mathrm{Ni}(\mathrm{II})$ and $\mathrm{DMG}$ at various $\mathrm{pHs}$. $\mathrm{A} \beta_{40}$ peptide $(25 \mu \mathrm{M})$ and thioflavin $(40 \mu \mathrm{M})$ were mixed in absence of metal or DMG (circles), in presence $25 \mu \mathrm{M} \mathrm{Ni}$ (II) (squares), or in presence of $10 \mu \mathrm{M} \mathrm{Zn(II)} \mathrm{(triangles).} \mathrm{The} \mathrm{final} \mathrm{pH} \mathrm{in} \mathrm{the} \mathrm{reaction} \mathrm{was} 6.5$ (white symbols), 7.5 (grey symbols), or 8.5 (black symbols). For instance, black triangles represent RFUs measured in presence of $\mathrm{Zn}(\mathrm{II})$ at $\mathrm{pH}$ 8.5. ThT-based fluorescence was measured every 3 min for $120 \mathrm{~min}$. A ThT-only background control (no A $\beta_{40}$ peptide) was included in the assay (data not shown). Results shown for each time point represent the mean and standard deviation (error bars) of background-subtracted values for triplicate wells.

$\Delta \mathrm{H}$ (enthalpy) and $\Delta \mathrm{S}$ (entropy) were found to be $-5 \mathrm{~kJ} / \mathrm{mol}$ and $86 \mathrm{~mol} / \mathrm{J} / \mathrm{K}$, suggesting the $\mathrm{Ni}$ - $\mathrm{A} \beta_{40}$ binding event can be considered both exothermic and spontaneous. Injection of DMG (instead of nickel) into the sample cell containing $\mathrm{A} \beta_{40}$ peptide did not induce any significant change, indicating that DMG cannot bind to the peptide (data not shown). Hence, this result suggests the inhibitory effect of DMG on $\mathrm{A} \beta_{40}$ peptide aggregation, as observed with ThT-based assays, is due to nickel chelation, rather than direct DMG-A $\beta_{40}$ peptide inhibitory interaction.

DMG-metal complexes can be detected by FTICR-MS. Aqueous solutions containing only DMG, or DMG in combination with $\mathrm{Ni}, \mathrm{Cu}, \mathrm{Fe}$, Se or $\mathrm{Zn}$ salts were analyzed using Fourier Transform Ion Cyclotron Resonance Mass Spectrometry (FTICR-MS). In absence of added metal, two monomeric isoforms were detected, corresponding to either DMG, $\mathrm{H}^{+}(117.06585 \mathrm{~m} / \mathrm{z})$ or DMG, $\mathrm{Na}^{+}(139.04780 \mathrm{~m} / \mathrm{z})($ Supplementary Fig. S1). In presence of $\mathrm{Ni}$, complexes consisting of two DMG and one $\mathrm{Ni}$, with either $\mathrm{H}^{+}(289.04412 \mathrm{~m} / \mathrm{z})$ or $\mathrm{Na}^{+}(311.02607 \mathrm{~m} / \mathrm{z})$ were detected. This was expected, as two DMG are required to chelate one Ni (Supplementary Fig. S1). Surprisingly, FTICR-MS analysis of a DMG-Ni aqueous solution further revealed the presence of [DMG $_{4}-(\mathrm{Ni})_{2}$ complexes, mostly in the $\mathrm{Na}+$ form $(599.06292 \mathrm{~m} / \mathrm{z})(\text { Supplementary Fig. S1). While [DMG }]_{2}-\mathrm{Cu}$ complexes were identified, only monomeric DMG $\left(\mathrm{H}^{+}\right.$or $\left.\mathrm{Na}^{+}\right)$was observed in presence of Fe, $\mathrm{Zn}$ or Se; no dimeric or tetrameric DMG-Se or DMG-Zn complexes could be detected, suggesting DMG does not coordinate with Fe, Zn or Se (Supplementary Fig. S1).

Analysis of DMG in brain samples using FTICR-MS and NMR. The fact that DMG inhibits A $\beta_{40}$ peptide aggregation in vitro suggests it might be able to do the same in vivo, however DMG would first need to cross the blood-brain barrier (BBB). To determine whether DMG can localize to the mouse brain, we used FTICR-MS (see above) and Nuclear Magnetic Resonance (NMR). NMR was successfully used to detect DMG in the livers of mice subjected to daily oral doses $(6.1 \mathrm{mg})$ of aqueous DMG for 3 days ${ }^{55}$. In the present study, the same treatment was administered (e.g. one daily oral delivery for 3 days), brain samples were processed and analyzed by NMR and FTICR-MS and compared to brain samples from (no DMG) control mice. Unfortunately, both methods failed to identify DMG (whether by itself or metal-chelated) in brain samples.

\section{Discussion}

To study $\mathrm{A} \beta$ peptide in vitro aggregation, one can choose to use either chemically synthetic peptides, or recombinant peptides, expressed in, and purified from, organisms such as $E$. coli. Synthetic A $\beta$ preparations have been associated with various problems, such as presence of impurities in the preparation, incorporation of the L-form of amino-acids (e.g. D-His, D-Met, D-Arg) instead of the L-form during synthesis, or reproducibility issues in terms of quality and yield, to a point that even batch-to-batch variations have been reported ${ }^{56-58}$. On the other 


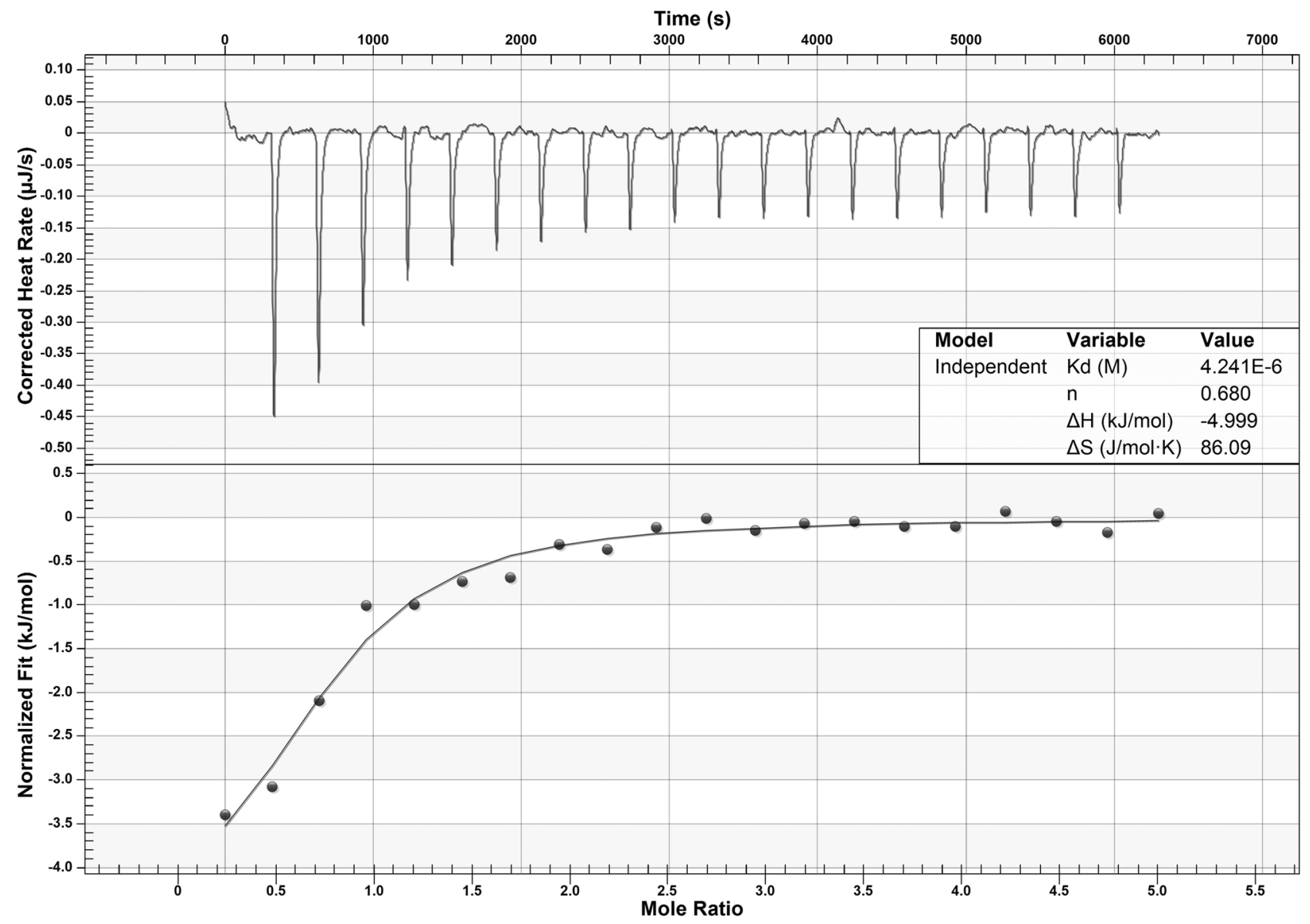

Figure 3. Isothermal titration calorimetry analysis of $\mathrm{Ni}$ binding to $\mathrm{A} \beta_{40}$. Top panel shows the raw data of heat release per injection, for 20 consecutive injections $(2.38 \mu \mathrm{L})$ of $\mathrm{NiSO}_{4}(1 \mathrm{mM})$ into a $500-\mu \mathrm{L}$ cell containing $\mathrm{A} \beta_{40}$ $(20 \mu \mathrm{M})$. Bottom panel shows binding isotherms, obtained by integrating the areas of each injection peak. Data acquired with a NanoITC were analyzed using NanoAnalyze 1.2 software(TA Instruments). Shown in the inset are the best-fit values for the dissociation constant $\left(K_{d}\right)$, stoichiometry $(\mathrm{n})$, enthalpic change $(\Delta \mathrm{H})$, and entropic change $(\Delta S)$.

hand, the expression and purification of recombinant $\mathrm{A} \beta$ peptides also bring their own limitations and issues, including low yield, reduced solubility and presence of oxidized amino-acids (e.g. $\mathrm{Met}_{35}$-sulfoxide) ${ }^{58}$. One major difference between synthetic and recombinant $\mathrm{A} \beta$ peptides though, often overlooked in the literature, is the absence and presence of metals associated with each preparation, respectively. Indeed, any protein or peptide showing natural affinity for one (or several) metal(s), as it is the case with $\mathrm{A} \beta$ peptides for copper or zinc ${ }^{24}$, will likely encounter (and bind to) the metals within the host (E. coli or other hosts). Hence recombinant A $\beta$ peptides are likely to be already associated with metals upon purification, in contrast to synthetic peptides. Given that both $\mathrm{Cu}$ and $\mathrm{Zn}$ enhance $\mathrm{A} \beta$ peptide aggregation, one can expect that $\mathrm{Cu}$ or/and $\mathrm{Zn}$-containing recombinant $\mathrm{A} \beta$ peptide will be "naturally" more prone to aggregation than their synthetic counterparts. This could account for differences reported in a study by Finder and coworkers, who found that recombinant $\mathrm{A} \beta_{42}$ peptides (likely metal-bound) aggregated faster and were more neurotoxic than synthetic $\mathrm{A} \beta_{42}$ peptides (likely metal-depleted) ${ }^{58}$. In order to validate our hypothesis (e.g. recombinant $\mathrm{A} \beta$ peptides are metal-rich) we subjected a commercial recombinant $\mathrm{A} \beta_{40}$ peptide preparation to ICP-MS metal analysis. Results unambiguously showed the presence of various metals, including $\mathrm{Al}, \mathrm{Cu}, \mathrm{Mn}, \mathrm{Zn}$, Se and $\mathrm{Ni}$, the two latter elements being by far the most abundant (ppm range). Additional metal analysis of other components of the commercial kit revealed the presence of $\mathrm{Al}, \mathrm{Cu}, \mathrm{Fe}, \mathrm{Mn}$, and $\mathrm{Ni}$, but no Se; furthermore, components-associated $\mathrm{Ni}$ levels were negligible compared to the peptide-associated Ni levels. Metallic ions, more especially $\mathrm{Cu}(\mathrm{II})$ and $\mathrm{Zn}(\mathrm{II})$, have been shown to enhance in vitro aggregation of both $\mathrm{A} \beta_{40}$ and $\mathrm{A} \beta_{42}$ peptides $^{19,27-30}$. Ni(II) can now be added to the list of $\mathrm{A} \beta$ peptideaggregating metals, based on results from the present study. Indeed, our thioflavin-based assays revealed that $\mathrm{Ni}(\mathrm{II})$ enhance $\mathrm{A} \beta_{40}$ aggregation, whereas DMG-mediated Ni-chelation inhibits it . Moreover, Ni(II) was found to be more efficient than $\mathrm{Cu}(\mathrm{II})$, and less efficient than $\mathrm{Zn}(\mathrm{II})$, respectively, at promoting $\mathrm{A} \beta_{40}$ aggregation, under the conditions tested in our study. Since various parameters (such as $\mathrm{pH}$ and temperature) have been previously shown to have an effect on metal-induced aggregation ${ }^{30,59}$, we tested the effect of $\mathrm{pH}$ on Ni-dependent aggregation. Three buffers with similar salt content $(192 \mathrm{mM} \mathrm{NaCl})$ but various $\mathrm{pHs}(6.5,7.5$, or 8.5$)$ were used. Interestingly, acidic $\mathrm{pH}$ (6.5) conditions increased $\mathrm{Ni}$-induced aggregation compared to the control $\mathrm{pH}(7.5)$, 
whereas $\mathrm{Ni}$-induced aggregation was abolished at $\mathrm{pH}$ 8.5. The increased $\mathrm{Ni}$-induced aggregation at acidic $\mathrm{pH}$, as observed in the present study, is in agreement with previous published data from Atwood et al., who reported an increase of $\mathrm{A} \beta_{1-40}$ aggregation in presence of $1 \mu \mathrm{M}$ Ni at $\mathrm{pH} 6.6$, compared to $\mathrm{pH} 7.4^{30}$. Likewise, the same study correlated acidic $\mathrm{pH}$ (6.6) with enhanced aggregation, in presence of either $\mathrm{Cu}$ or $\mathrm{Zn}$ (both at $20 \mu \mathrm{M}$ ). Herein, $\mathrm{Zn}$-induced aggregation was slightly higher at $\mathrm{pH} 7.5$ compared to 6.5, and significantly faster compared to $\mathrm{pH}$ 8.5. The effect of $\mathrm{pH}$ on $\mathrm{Cu}$-induced aggregation was negligible, but it is worth noting that the effect of $\mathrm{Cu}$ was very limited throughout our ThT-based assays, for a reason yet to be determined. The effect of temperature on $\mathrm{Ni}$-dependent $\mathrm{A} \beta_{40}$ aggregation was not tested with the fluorescence-based method, as all assays were carried out at $37^{\circ} \mathrm{C}$. However, $\mathrm{Ni}-\mathrm{A} \beta_{40}$ binding was also observed at $25^{\circ} \mathrm{C}$, as shown by ITC (see below). Although results obtained with both methods cannot be directly compared nevertheless we can report that Ni binding (to A $\beta 40$ ) happens both at $25^{\circ} \mathrm{C}$ and $37^{\circ} \mathrm{C}$.

Since aggregation in presence of a particular metal (e.g., nickel) suggests initial metal-peptide binding, we further investigated the likelihood of $\mathrm{Ni}$ binding to $\mathrm{A} \beta_{40}$, by using ITC. The calorimetry-based method has been successfully used in the past to study $\mathrm{Zn}$ binding to $\mathrm{A} \beta_{40}$, both at low $(10 \mu \mathrm{M})$ and high $(70 \mu \mathrm{M})$ concentrations $^{53}$. In the current study, we only looked at the effect of $\mathrm{Ni}$ on low $\mathrm{A} \beta_{40}$ concentration, with a starting concentration of $\mathrm{A} \beta_{40}$ in the sample cell at $20 \mu \mathrm{M}$. After Ni was injected via 20 consecutive injections, every $5 \mathrm{~min}(5 \mu \mathrm{M}$ increments), a heat profile characteristic of independent metal-binding was observed. Although the apparent $\mathrm{K}_{\mathrm{d}}(4.2 \mu \mathrm{M})$ is similar to that reported for $\mathrm{Zn}^{53}$, the apparent stoichiometry $\left(0.7 \mathrm{~mol}\right.$ of Ni per mole of $\left.\mathrm{A} \beta_{40}\right)$ is significantly lower than that previously reported by Drochioiu and colleagues, who found that synthetic $\mathrm{A} \beta_{40}$ peptide displays high affinity toward nickel ions with up to three $\mathrm{Ni}^{2+}$ ions bound per $\mathrm{A} \beta_{40}$ peptide ${ }^{60}$. However, the discrepancy between our results and theirs could be due to the nature of $\mathrm{A} \beta_{40}$ peptide used, and the type of analytical method used to analyze $\mathrm{Ni}-\mathrm{A} \beta_{40}$. In our study, we used a purified recombinant $\mathrm{A} \beta_{40}$ peptide, and ITC, whereas Drochioiu et al. used synthetic $\mathrm{A} \beta_{40}$ peptide, electrospray ion trap mass spectrometry (ESI-MS) and circular dichroism (CD). Nevertheless, results from both groups indicate that $\mathrm{A} \beta_{40}$ can bind nickel with high affinity. Furthermore, our results confirm that DMG inhibits $\mathrm{A} \beta_{40}$ aggregation through Ni chelation (not direct contact with the peptide), since titration of the peptide with DMG did not induce any peptide conformational change, as observed with ITC.

Given the presence of $\mathrm{Cu}^{2+}, \mathrm{Ni}^{2+}, \mathrm{Zn}^{2+}$ in recombinant $\mathrm{A} \beta_{40}$ peptide, combined to their respective effect on $\mathrm{A} \beta_{40}$ peptide aggregation, metal chelation therapy towards $\mathrm{AD}$ constitutes a valid approach. However, the risk of chelation therapy is that removal of essential metal ions will lead to serious adverse effects (for instance, irondeficiency anemia) as pointed out by other researchers ${ }^{35}$. Hence it is preferable to use chelators with select affinity towards non-essential metals: the Ni-specific chelator DMG is therefore a good candidate. Indeed, DMG has been used for many years to detect, quantitate or decrease Ni levels in various environments; it can also be used to inhibit the growth of bacteria, including multidrug resistant Enterobacteriaceae, as recently demonstrated by our group $^{55}$. Mammalian hosts do not contain known Ni-dependent enzymes, which makes Ni-chelation therapy an attractive approach ${ }^{47}$. On the other hand, most bacteria, including pathogenic ones, require nickel as cofactor for one or several enzymes, such as [Ni-Fe] hydrogenase $(s)^{61}$ or urease ${ }^{47}$. Thus, DMG-mediated inhibition of these enzymes, as demonstrated with Salmonella Typhimurium hydrogenases or Klebsiella pneumoniae urease, leads to bacterial growth inhibition, both in the mouse and in the wax moth animal models ${ }^{55}$. In the present study, we showed that DMG can drastically reduce, and even abolish $\mathrm{A} \beta_{40}$ peptide aggregation. The inhibitory effect was observed in absence of supplemental metal, as well as in presence of copper, nickel or even zinc (albeit with lower efficacy). Although thioflavin is a popular reporter of amyloid aggregation, it mostly binds to $\beta$-sheet rich fibrils ${ }^{62,63}$. Therefore, our conclusions on the effect of Ni and Ni-chelation (DMG) on A $\beta$ peptide-aggregation must be limited at this time to the $\beta$-sheet content. Additional experiments will be needed to determine whether $\mathrm{Ni}$ and its chelator have a broader effect on other $\mathrm{A} \beta$ peptide conformations. Likewise, further experiments will be conducted to test whether DMG can inhibit the aggregation of other physiologically relevant $\mathrm{A} \beta$ peptides, for instance $\mathrm{A} \beta_{42}$.

The current study is not the first one to report inhibitory effect of a nickel chelator on $\mathrm{A} \beta$ peptide aggregation. Indeed, Reinhardt and colleagues reported beneficial effects of the nickel chelator disulfiram on AD hallmarks, including inhibitory effects on $\mathrm{A} \beta_{42}$ peptide aggregation ${ }^{64}$. The study however was not aimed at establishing any link between $\mathrm{Ni}$ and $\mathrm{AD}$. The authors found that disulfiram increased synthesis of the metalloproteinase $\alpha$-secretase, resulting in secretion of the neuroprotective APP cleavage product sAPP $\alpha$ and thus preventing formation of the amyloidogenic $\beta$ A peptides ${ }^{64}$. The concentration of disulfiram shown to have inhibitory effects on peptide aggregation was significantly lower compared to DMG concentrations used in our study, however the disulfiram drug is highly toxic, even at low doses, with concentrations higher than $5 \mu \mathrm{M}$ inducing cytotoxicity ${ }^{64}$. This finding correlates with previous studies linking disulfiram with negative outcomes, such as elevated nickel levels in rat brains ${ }^{65}$, elevated nickel levels in body fluids of patients with chronic alcoholism ${ }^{65,66}$, as well as hepatotoxicity in humans ${ }^{67,68}$.

If $\mathrm{DMG}$ were to be used in a clinical trial against $\mathrm{AD}$, it might not only inhibit $\mathrm{A} \beta$ plaque formation, but also Ni-requiring microorganisms. This, however, would not necessarily be a negative outcome, in light of the link

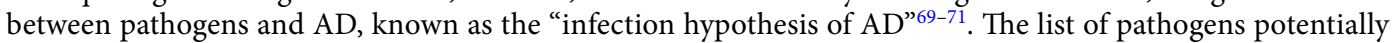
linked to AD includes viral, fungal and bacterial species. Among bacteria directly or indirectly associated with $\mathrm{AD}$, one can find Helicobacter pylori ${ }^{72,73},{\text { E. } \text { coli }^{74} \text { and Salmonella Typhimurium }}^{75}$, all of which require Ni as cofactor for one or several enzymes (for a review, see Maier and Benoit ${ }^{47}$ ). In the case of $H$. pylori, another protein is relevant to the pathogen/AD link. The gastric pathogen produces abundant amounts ( $2 \%$ of total protein) of a small histidine-rich protein (Hpn) that has been shown to develop amyloid-like fibrils in vitro ${ }^{76}$. The continuous production of Hpn by the bacterium during decades of chronic gastric infection could result in leakage of the protein, first into the bloodstream and eventually into the brain, potentially triggering $\mathrm{AD}$, as hypothesized by Ge and $\operatorname{Sun}^{77}$. More generally, an antimicrobial role for $\mathrm{A} \beta$ peptides (as part of the brain's ancient immune system) 


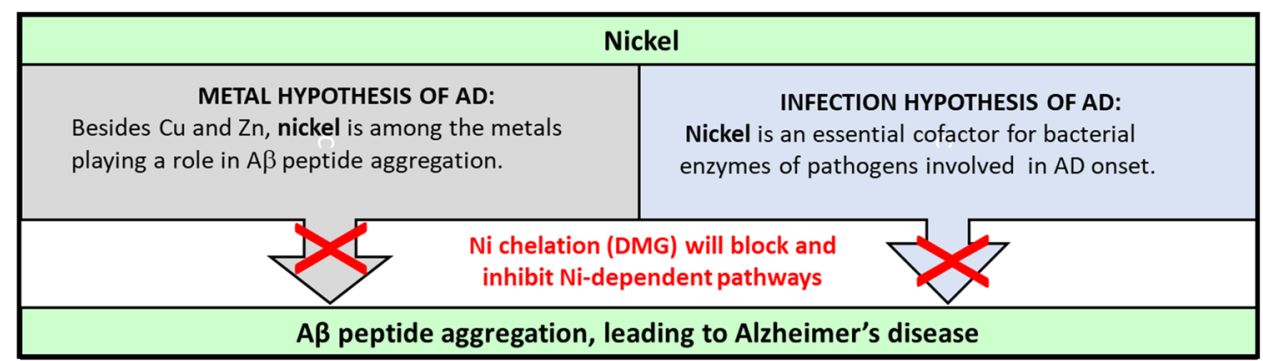

Figure 4. Hypothetical model showing a dual role for nickel (Ni) and a proposed mode of action for DMGmediated Ni chelation. Ni can bind to $\mathrm{A} \beta$ peptides, leading to aggregation and plaque formation (left side, metal hypothesis of $\mathrm{AD}$ ). In addition, $\mathrm{Ni}$ is required as cofactor for enzymes (such as hydrogenase and urease) of pathogens previously shown to play a role in $\mathrm{A} \beta$ peptide aggregation (right side, infection hypothesis of $\mathrm{AD}$ ). The Ni-chelator DMG could inhibit $\mathrm{A} \beta$ peptide aggregation and the progression of $\mathrm{AD}$ (red crosses), either directly (left side) or indirectly (through pathogen inhibition, right side).

has been proposed, as part of a "new amyloidogenesis model"78. The model is based on findings by Kumar and colleagues, who reported ${ }^{75}$ that bacterial infection of the brains of transgenic mice result in accelerated $\mathrm{A} \beta$ plaque deposition, closely colocalizing with the invading bacteria (in this case, Salmonella) ${ }^{75}$.

In summary, Ni could affect the onset and the progression of $\mathrm{AD}$ through two different mechanisms, as depicted in our proposed model (Fig. 4). The first mechanism involves the binding of $\mathrm{Ni}^{2+}$ to $\mathrm{A} \beta$ ( $\mathrm{A} \beta_{40}$, possibly $\mathrm{A} \beta_{42}$ ), eventually leading to aggregation, plaque formation and $\mathrm{AD}$; this would comply with the metal hypothesis of $\mathrm{AD}$. The second mechanism involves the use of $\mathrm{Ni}^{2+}$ as a required cofactor for various enzymes (e.g. Niglyoxalase, Ni-superoxide dismutase, $\mathrm{Ni}$-acireductone dioxygenase, [NiFe] hydrogenases and urease, $\left.\mathrm{see}^{47}\right)$ of pathogens previously shown to play a role in $\mathrm{A} \beta$ peptide aggregation; alternatively some of these pathogens might contribute to $\mathrm{AD}$ independently of $\mathrm{A} \beta$ plaque formation. Both scenarios would fit the "infectious hypothesis of AD". Whether one Ni-dependent mechanism is preferred over the other, or both actively contribute to the onset and/or the progression of $\mathrm{AD}$, nevertheless a DMG-mediated Ni-chelation strategy is at the intersection of both (the metal and the infectious) hypotheses. Thus, it is likely to interfere and disrupt both mechanisms, eventually slowing down or stopping the progression of AD. More than a century after Alois Alzheimer fist described the disease, and without any cure on the horizon, new therapeutic strategies are urgently needed to combat this neurodegenerative disease; we believe that nickel chelation (via DMG treatment) is a promising AD-combatting strategy that warrants further research.

\section{Materials and methods}

Chemicals. The water-soluble form $\left(2 \mathrm{Na}, 8 \mathrm{H}_{2} \mathrm{O}\right)$ of DMG was used in this study (ref \# 40400, HoneywellFluka, Muskegon, MI, USA). All metals $\left(\mathrm{CuSO}_{4}, \mathrm{FeSO}_{4}, \mathrm{Na}_{2} \mathrm{SeO}_{3}, \mathrm{NiCl}_{2}, \mathrm{NiSO}_{4}, \mathrm{ZnSO}_{4}\right)$ are from Sigma-Aldrich (Saint Louis, MO, USA).

Amyloid beta metal analysis. Metal levels for 20 elements ( $\mathrm{Li}, \mathrm{Be}, \mathrm{Al}, \mathrm{V}, \mathrm{Cr}, \mathrm{Mn}, \mathrm{Fe}, \mathrm{Co}, \mathrm{Ni}, \mathrm{Cu}, \mathrm{Zn}, \mathrm{As}$, $\mathrm{Se}, \mathrm{Rb}, \mathrm{Sr}, \mathrm{Cd}, \mathrm{Cs}, \mathrm{Ba}, \mathrm{Pb}, \mathrm{U}$ ) were determined by inductively coupled plasma mass spectrometry (ICP-MS). Briefly, $0.5 \mathrm{mg}$ of lyophilized human recombinant $\mathrm{A} \beta_{40}$ peptide (expressed in $E$. coli, purified and manufactured by rPeptides, Watkinsville, GA) was resuspended in ultrapure water to a final concentration of $5 \mathrm{mg} / \mathrm{mL}$, digested overnight with concentrated trace metal grade nitric acid, heated for $2 \mathrm{~h}$ at $95{ }^{\circ} \mathrm{C}$ and subjected to ICPMS using a Thermo X-Series II ICP-MS (Center for Applied Isotope Studies, University of Georgia, Athens, GA). The same treatment and analysis were performed on three other kit components: TBS 10X (reaction buffer), Thioflavin stock $(400 \mu \mathrm{M})$ and $\mathrm{NaOH} 10 \mathrm{mM}$ (used to resuspend the $\mathrm{A} \beta_{40}$ peptide).

Amyloid beta aggregation. The effect of metals, DMG, and/or pH on human recombinant $\mathrm{A} \beta_{40}$ aggregation was monitored using a thioflavin T (ThT)-based kit, following the manufacturer's recommendation (kit\# A-1180-1, rPeptides, Watkinsville, GA, USA). This kit contains human recombinant $A \beta_{40}$ peptide (>97\% pure, as determined by manufacturer's HPLC) with the following sequence DAEFRHDSGYEVHHQKLVFFAEDVGSNKGAIIGLMVGGVV, as provided by the manufacturer. Briefly, standard assays were conducted in triplicate in black polystyrene 96-well plates, in presence of Tris Buffer Saline (TBS) pH 7.4, or TBS pH 8.5, or 2-(N-morpholino)ethanesulfonic acid (MES) buffer saline $\mathrm{pH} 6.5$, Th- T $(20$ or $40 \mu \mathrm{M})$, and human recombinant $\mathrm{A} \beta_{40}$ peptide $(25$ or $40 \mu \mathrm{M})$, with or without DMG $(100,500$, or $1000 \mu \mathrm{M}), \mathrm{CuSO}_{4}, \mathrm{NiSO}_{4}$ or $\mathrm{ZnSO}_{4}(10,25$, or $100 \mu \mathrm{M})$. The aggregation of $A \beta_{40}$, as shown by the increase in fluorescence $(\lambda e x=440 \mathrm{~nm} / \lambda \mathrm{em}=485 \mathrm{~nm})$ over time, was followed for $60 \mathrm{~min}$ or $120 \mathrm{~min}$, with reading every 3 or $5 \mathrm{~min}$, using a Synergy MX reader (Biotek, Winooski, VT). A ThT-only background control (no A $\beta_{40}$ peptide) was included in triplicate in all experiments and subtracted from all readings. The aggregation rate, defined as the increase in fluorescence per $\mathrm{min}(\mathrm{RFU} / \mathrm{min})$, was calculated by using the formula $\left[\mathrm{A}(440,485)\right.$ at $\left.\mathrm{T}_{40 \mathrm{~min}}\right)-\mathrm{A}_{(440,485)}$ at $\left.\mathrm{T}_{20 \mathrm{~min}}\right] / 20$. These time points $(20$ to $40 \mathrm{~min})$ were chosen because they constantly displayed the best linearity in every assay. Results shown are expressed as (mean and standard deviation of) percentages; they represent the ratio of aggregation rate (RFU/min) for a given 
(DMG, metal) condition, compared to the aggregation rate obtained for the control ( $\mathrm{A} \beta_{40}$ peptide, no DMG, no metal added, set as $100 \%$ for each experiment).

Isothermal titration calorimetry. Binding assays of $\mathrm{A} \beta_{40}$ peptide and Ni or DMG were performed using a Nano ITC calorimeter (TA instruments, New Castle, DE). Briefly, $1 \mathrm{mg}$ of lyophilized A $\beta_{40}$ peptide (\# A-11572 , rPeptides) was resuspended with $1 \% \mathrm{NH}_{4} \mathrm{OH}$ to a concentration of $250 \mu \mathrm{M}$, sonicated for 15-20 s, before being diluted to a final concentration of $20 \mu \mathrm{M} \mathrm{A} \beta_{40}$ using $\mathrm{ddH}_{2} \mathrm{O}$ and TBS 10X, pH 7.4 (working buffer: $\mathrm{NH}_{4} \mathrm{OH}$ $0.2 \%$, TBS $1 \mathrm{X}, \mathrm{pH} 7.4$ ("NTBS")). A volume of $500 \mu \mathrm{L}$ was loaded onto the ITC sample cell, and the injection syringe was filled with $50 \mu \mathrm{L}$ of either NTBS buffer (control), $1 \mathrm{mM} \mathrm{NiSO}_{4}$, or $1 \mathrm{mM} \mathrm{DMG}$. All samples were degassed for $15 \mathrm{~min}$ at $25^{\circ} \mathrm{C}$ before use. Titration was initiated using a program for 20 injections $(2.38 \mu \mathrm{L}$ each, every $5 \mathrm{~min})$ with continuous stirring $(350 \mathrm{rpm})$ at constant temperature $\left(25^{\circ} \mathrm{C}\right)$. ITC data were analyzed using NanoAnalyze 1.2 software (TA Instruments). Data obtained with the control experiment (A $\beta_{40}$ peptide in sample cell, buffer in syringe) were subtracted from each experiment to account for any injection-related heat change. The $\mathrm{Ni}-\mathrm{A} \beta_{40}$ experiment was done in triplicate, with a representative data set shown in figures.

Analysis of DMG and DMG-metal complexes in commercial preparations. Aqueous solutions of $\mathrm{DMG}(0.5 \mathrm{mg} / \mathrm{mL}$ or $1.6 \mathrm{mM})$, with or without $\mathrm{Cu}, \mathrm{Fe}, \mathrm{Ni}$, Se or $\mathrm{Zn}$ solutions $(0.16 \mathrm{mM}$ each) were analyzed by Fourier Transform Ion Cyclotron Resonance Mass Spectrometry (FTICR-MS), using a Bruker Solari X ESI/ MALDI-12 T FT-ICR high precision mass spectrometer (Proteomics and Mass Spectrometry Facility, University of Georgia). The $\mathrm{pH}$ of all aqueous DMG solutions, with or without metal, was approximately 11. All samples were mixed (1:1) with methanol prior to injection.

Detection of DMG and DMG-metal complexes in mouse brains. All procedures were performed in accordance with the relevant guidelines and regulations and approved by the University of Georgia IACU committee, and the study was carried out in compliance with the ARRIVE guidelines (http://www.nc3rs.org.uk/page. asp?id=1357). A group of $6(\mathrm{C} 57 / \mathrm{BL})$ mice was used for this experiment: 3 mice were given $0.2 \mathrm{~mL}$ of $100 \mathrm{mM}$ DMG ( $6.1 \mathrm{mg})$ every day for three days and 3 mice were used as (no DMG) controls. Mice were euthanized by $\mathrm{CO}_{2}$ asphyxiation and cervical dislocation. Brains were quickly removed and frozen at $-80^{\circ} \mathrm{C}$. Upon thawing, brains were cut into pieces and homogenized in $2 \mathrm{~mL}$ sterile deionized water, incubated for $1 \mathrm{~h}$ at $90^{\circ} \mathrm{C}$, sonicated for $20 \mathrm{~s}$ and spun down $(16,800 \times \mathrm{g}$ for $6 \mathrm{~min})$. Supernatants were passaged through a $0.45 \mu \mathrm{m}$ filter unit and analyzed by FTICR-MS (see above) and Nuclear Magnetic Resonance (NMR), as previously described ${ }^{55}$.

Received: 15 December 2020; Accepted: 5 March 2021

Published online: 23 March 2021

\section{References}

1. Alzheimer, A. Über eine eigenartige Erkrankung der Hirnrinde [About a peculiar disease of the cerebral cortex]. Allgemeine Zeitschrift fur Psychiatrie und Psychisch-Gerichtlich Medizin 64, 146-148 (1907).

2. Kochanek, K. D., Murphy, S. L., Xu, J. \& Arias, E. Deaths: final data for 2017. (2019).

3. Zetterberg, H., Blennow, K. \& de Leon, M. Alzheimer's disease. Lancet 368, 387 (2006).

4. Jebarupa, B., Muralidharan, M., Arun, A., Mandal, A. K. \& Mitra, G. Conformational heterogeneity of tau: Implication on intrinsic disorder, acid stability and fibrillation in Alzheimer's disease. Biophys. Chem. 241, 27-37. https://doi.org/10.1016/j.bpc.2018.07. 005 (2018)

5. Hardy, J. A. \& Higgins, G. A. Alzheimer's disease: the amyloid cascade hypothesis. Science 256, 184-185 (1992).

6. Tharp, W. G. \& Sarkar, I. N. Origins of amyloid- $\beta$. BMC Genom. 14, 290 (2013).

7. Haass, C. \& Selkoe, D. J. Cellular processing of $\beta$-amyloid precursor protein and the genesis of amyloid $\beta$-peptide. Cell 75, 1039-1042 (1993).

8. Galante, D. et al. Differential toxicity, conformation and morphology of typical initial aggregation states of Abeta1-42 and Abetapy3-42 beta-amyloids. Int. J. Biochem. Cell. Biol. 44, 2085-2093. https://doi.org/10.1016/j.biocel.2012.08.010 (2012).

9. Seubert, P. et al. Isolation and quantification of soluble Alzheimer's beta-peptide from biological fluids. Nature 359, 325-327. https://doi.org/10.1038/359325a0 (1992).

10. Vigo-Pelfrey, C., Lee, D., Keim, P., Lieberburg, I. \& Schenk, D. B. Characterization of beta-amyloid peptide from human cerebrospinal fluid. J. Neurochem. 61, 1965-1968. https://doi.org/10.1111/j.1471-4159.1993.tb09841.x (1993).

11. Ida, N. et al. Analysis of heterogeneous A4 peptides in human cerebrospinal fluid and blood by a newly developed sensitive Western blot assay. J. Biol. Chem. 271, 22908-22914. https://doi.org/10.1074/jbc.271.37.22908 (1996).

12. Haass, C. et al. Amyloid $\beta$-peptide is produced by cultured cells during normal metabolism. Nature 359, 322-325 (1992).

13. Ivanova, M. I., Lin, Y., Lee, Y. H., Zheng, J. \& Ramamoorthy, A. Biophysical processes underlying cross-seeding in amyloid aggregation and implications in amyloid pathology. Biophys. Chem. 269, 106507. https://doi.org/10.1016/j.bpc.2020.106507 (2021).

14. Saunders, A. M. et al. Association of apolipoprotein E allele epsilon 4 with late-onset familial and sporadic Alzheimer's disease. Neurology 43, 1467-1472. https://doi.org/10.1212/wnl.43.8.1467 (1993).

15. Giri, M., Zhang, M. \& Lü, Y. Genes associated with Alzheimer's disease: an overview and current status. Clin. Interv. Aging 11, 665 (2016).

16. Gatz, M. et al. Role of genes and environments for explaining Alzheimer disease. Arch. Gen. Psychiatry 63, 168-174 (2006).

17. Saranya, V., Mary, P. V., Vijayakumar, S. \& Shankar, R. The hazardous effects of the environmental toxic gases on amyloid betapeptide aggregation: A atheoretical perspective. Biophys. Chem. 263, 106394. https://doi.org/10.1016/j.bpc.2020.106394 (2020).

18. Liu, Y., Nguyen, M., Robert, A. \& Meunier, B. Metal ions in Alzheimer's disease: a key role or not?. Acc. Chem. Res. 52, $2026-2035$. https://doi.org/10.1021/acs.accounts.9b00248 (2019).

19. Ricchelli, F., Drago, D., Filippi, B., Tognon, G. \& Zatta, P. Aluminum-triggered structural modifications and aggregation of $\beta$-amyloids. Cell. Mol. Life Sci. CMLS 62, 1724-1733 (2005).

20. Notarachille, G., Arnesano, F., Calò, V. \& Meleleo, D. Heavy metals toxicity: effect of cadmium ions on amyloid beta protein 1-42. Possible implications for Alzheimer's disease. Biometals 27, 371-388 (2014). 
21. Olivieri, G. et al. Mercury induces cell cytotoxicity and oxidative stress and increases $\beta$-amyloid secretion and tau phosphorylation in SHSY5Y neuroblastoma cells. J. Neurochem. 74, 231-236 (2000).

22. Meleleo, D., Sblano, C., Storelli, M. M. \& Mallamaci, R. Evidence of cadmium and mercury involvement in the A $\beta 42$ aggregation process. Biophys. Chem. 266, 106453. https://doi.org/10.1016/j.bpc.2020.106453 (2020).

23. Kozlowski, H., Luczkowski, M., Remelli, M. \& Valensin, D. Copper, zinc and iron in neurodegenerative diseases (Alzheimer's, Parkinson's and prion diseases). Coord. Chem. Rev. 256, 2129-2141 (2012).

24. Tôugu, V., Tiiman, A. \& Palumaa, P. Interactions of $\mathrm{Zn}(\mathrm{II})$ and $\mathrm{Cu}(\mathrm{II})$ ions with Alzheimer's amyloid-beta peptide. Metal ion binding, contribution to fibrillization and toxicity. Metallomics 3, 250-261. https://doi.org/10.1039/c0mt00073f (2011).

25. Mathys, Z. K. \& White, A. R. Copper and Alzheimer's disease. Neurotoxicity of Metals, 199-216 (2017).

26. Hureau, C. \& Faller, P. A $\beta$-mediated ROS production by $\mathrm{Cu}$ ions: structural insights, mechanisms and relevance to Alzheimer's disease. Biochimie 91, 1212-1217 (2009).

27. Bush, A. I. et al. Rapid induction of Alzheimer A beta amyloid formation by zinc. Science 265, 1464-1467. https://doi.org/10.1126/ science.8073293 (1994).

28. Chen, T. et al. Effects of cyclen and cyclam on zinc (II)-and copper (II)-induced amyloid $\beta$-peptide aggregation and neurotoxicity. Inorg. Chem. 48, 5801-5809 (2009).

29. Huang, X. et al. Zinc-induced Alzheimer's Abeta1-40 aggregation is mediated by conformational factors. J. Biol. Chem. 272, 26464-26470. https://doi.org/10.1074/jbc.272.42.26464 (1997).

30. Atwood, C. S. et al. Dramatic aggregation of Alzheimer abeta by $\mathrm{Cu}(\mathrm{II})$ is induced by conditions representing physiological acidosis. J. Biol. Chem. 273, 12817-12826. https://doi.org/10.1074/jbc.273.21.12817 (1998).

31. Sparks, D. L. \& Schreurs, B. G. Trace amounts of copper in water induce beta-amyloid plaques and learning deficits in a rabbit model of Alzheimer's disease. Proc. Natl. Acad. Sci. USA 100, 11065-11069. https://doi.org/10.1073/pnas.1832769100 (2003).

32. Lee, J. Y., Cole, T. B., Palmiter, R. D., Suh, S. W. \& Koh, J. Y. Contribution by synaptic zinc to the gender-disparate plaque formation in human Swedish mutant APP transgenic mice. Proc. Natl. Acad. Sci. USA. 99, 7705-7710. https://doi.org/10.1073/pnas.09203 4699 (2002)

33. Lovell, M. A., Robertson, J. D., Teesdale, W. J., Campbell, J. L. \& Markesbery, W. R. Copper, iron and zinc in Alzheimer's disease senile plaques. J. Neurol. Sci. 158, 47-52. https://doi.org/10.1016/s0022-510x(98)00092-6 (1998).

34. Miller, L. M. et al. Synchrotron-based infrared and X-ray imaging shows focalized accumulation of Cu and Zn co-localized with beta-amyloid deposits in Alzheimer's disease. J. Struct. Biol. 155, 30-37. https://doi.org/10.1016/j.jsb.2005.09.004 (2006).

35. Bush, A. I. \& Tanzi, R. E. Therapeutics for Alzheimer's disease based on the metal hypothesis. Neurotherapeutics 5, 421-432. https:// doi.org/10.1016/j.nurt.2008.05.001 (2008).

36. Santos, M. A., Chand, K. \& Chaves, S. Recent progress in multifunctional metal chelators as potential drugs for Alzheimer's disease. Coord. Chem. Rev. 327, 287-303 (2016).

37. Cherny, R. A. et al. Aqueous dissolution of Alzheimer's disease Abeta amyloid deposits by biometal depletion. J. Biol. Chem. 274, 23223-23228. https://doi.org/10.1074/jbc.274.33.23223 (1999).

38. Cherny, R. A. et al. Treatment with a copper-zinc chelator markedly and rapidly inhibits beta-amyloid accumulation in Alzheimer's disease transgenic mice. Neuron 30, 665-676. https://doi.org/10.1016/s0896-6273(01)00317-8 (2001).

39. Sampson, E. L., Jenagaratnam, L. \& McShane, R. Metal protein attenuating compounds for the treatment of Alzheimer's dementia. Cochrane Database Syst. Rev. 2, CD005380 (2014).

40. Crapper McLachlan, D. R. et al. Intramuscular desferrioxamine in patients with Alzheimer's disease. Lancet 337, 1304-1308. https://doi.org/10.1016/0140-6736(91)92978-b (1991).

41. Korshavn, K. J. et al. Reactivity of metal-free and metal-associated amyloid-beta with glycosylated polyphenols and their esterified derivatives. Sci. Rep. 5, 17842. https://doi.org/10.1038/srep17842 (2015).

42. DeToma, A. S. et al. Synthetic flavonoids, aminoisoflavones: interaction and reactivity with metal-free and metal-associated amyloid- $\beta$ species. Chem. Sci. 5, 4851-4862. https://doi.org/10.1039/c4sc01531b (2014).

43. Lee, H. J. et al. Structural and mechanistic insights into development of chemical tools to control individual and inter-related pathological features in Alzheimer's disease. Chemistry 23, 2706-2715. https://doi.org/10.1002/chem.201605401 (2017).

44. Lee, S. et al. Rational design of a structural framework with potential use to develop chemical reagents that target and modulate multiple facets of Alzheimer's disease. J. Am. Chem. Soc. 136, 299-310. https://doi.org/10.1021/ja409801p (2014).

45. Stellato, F. et al. The effect of $\beta$-sheet breaker peptides on metal associated Amyloid- $\beta$ peptide aggregation process. Biophys. Chem. 229, 110-114. https://doi.org/10.1016/j.bpc.2017.05.005 (2017).

46. Maret, W. Metalloproteomics, metalloproteomes, and the annotation of metalloproteins. Metallomics 2, 117-125. https://doi.org/ $10.1039 / \mathrm{b} 915804 \mathrm{a}$ (2010).

47. Maier, R. J. \& Benoit, S. L. Role of nickel in microbial pathogenesis. Inorganics 7, 80 (2019).

48. Iyengar, G. V., Kollmer, W. E. \& Bowen, H. J. M. The elemental composition of human tissues and body fluids: a compilation of values for adults. (Vch Pub, 1978).

49. Kim, S. H. et al. Rapid doubling of Alzheimer's amyloid- $\beta 40$ and 42 levels in brains of mice exposed to a nickel nanoparticle model of air pollution. F1000Research 1, 70 (2012).

50. Bush, A. I., Pettingell, W. H. Jr., Paradis, M. D. \& Tanzi, R. E. Modulation of A beta adhesiveness and secretase site cleavage by zinc. J. Biol. Chem. 269, 12152-12158 (1994).

51. Sacco, C., Skowronsky, R. A., Gade, S., Kenney, J. M. \& Spuches, A. M. Calorimetric investigation of copper (II) binding to A $\beta$ peptides: thermodynamics of coordination plasticity. J. Biol. Inorg. Chem. 17, 531-541 (2012).

52. Hatcher, L. Q., Hong, L., Bush, W. D., Carducci, T. \& Simon, J. D. Quantification of the binding constant of copper (II) to the amyloid-beta peptide. J. Phys. Chem. B 112, 8160-8164 (2008).

53. Talmard, C., Bouzan, A. \& Faller, P. Zinc binding to amyloid-beta: isothermal titration calorimetry and Zn competition experiments with Zn sensors. Biochemistry 46, 13658-13666. https://doi.org/10.1021/bi701355j (2007).

54. DeToma, A. S., Salamekh, S., Ramamoorthy, A. \& Lim, M. H. Misfolded proteins in Alzheimer's disease and type II diabetes. Chem. Soc. Rev. 41, 608-621. https://doi.org/10.1039/clcs15112f (2012).

55. Benoit, S. L. et al. Nickel chelation therapy as an approach to combat multi-drug resistant enteric pathogens. Sci. Rep. 9, 13851. https://doi.org/10.1038/s41598-019-50027-0 (2019).

56. Dobeli, H. et al. A biotechnological method provides access to aggregation competent monomeric Alzheimer's 1-42 residue amyloid peptide. Biotechnology (NY) 13, 988-993. https://doi.org/10.1038/nbt0995-988 (1995).

57. Zagorski, M. G. et al. Methodological and chemical factors affecting amyloid beta peptide amyloidogenicity. Methods Enzymol. 309, 189-204. https://doi.org/10.1016/s0076-6879(99)09015-1 (1999).

58. Finder, V. H., Vodopivec, I., Nitsch, R. M. \& Glockshuber, R. The recombinant amyloid- $\beta$ peptide A $\beta 1-42$ aggregates faster and is more neurotoxic than synthetic $\mathrm{A} \beta 1-42$. J. Mol. Biol. 396, 9-18 (2010).

59. Mantyh, P. W. et al. Aluminum, iron, and zinc ions promote aggregation of physiological concentrations of $\beta$-amyloid peptide. J. Neurochem. 61, 1171-1174 (1993).

60. Drochioiu, G. et al. Interaction of beta-amyloid(1-40) peptide with pairs of metal ions: an electrospray ion trap mass spectrometric model study. Biophys. Chem. 144, 9-20. https://doi.org/10.1016/j.bpc.2009.05.008 (2009).

61. Benoit, S. L., Maier, R. J., Sawers, R. G. \& Greening, C. Molecular hydrogen metabolism: a widespread trait of pathogenic bacteria and protists. Microbiol. Mol. Biol. Rev. 84, e00092-19 (2020). 
62. Streets, A. M., Sourigues, Y., Kopito, R. R., Melki, R. \& Quake, S. R. Simultaneous measurement of amyloid fibril formation by dynamic light scattering and fluorescence reveals complex aggregation kinetics. PLoS ONE 8, e54541. https://doi.org/10.1371/ journal.pone.0054541 (2013)

63. Xue, C., Lin, T. Y., Chang, D. \& Guo, Z. Thioflavin T as an amyloid dye: fibril quantification, optimal concentration and effect on aggregation. R. Soc. Open Sci. 4, 160696. https://doi.org/10.1098/rsos.160696 (2017).

64. Reinhardt, S. et al. Identification of disulfiram as a secretase-modulating compound with beneficial effects on Alzheimer's disease hallmarks. Sci. Rep. 8, 1-13 (2018).

65. Baselt, R. C. \& Hanson, V. W. Efficacy of orally-administered chelating agents for nickel carbonyl toxicity in rats. Res. Commun. Chem. Pathol. Pharmacol. 38, 113-124 (1982).

66. Hopfer, S. M. et al. Increased nickel concentrations in body fluids of patients with chronic alcoholism during disulfiram therapy. Res. Commun. Chem. Pathol. Pharmacol. 55, 101-109 (1987).

67. Kaaber, K., Menne, T., Tjell, J. C. \& Veien, N. Antabuse treatment of nickel dermatitis Chelation: a new principle in the treatment of nickel dermatitis. Contact Dermat. 5, 221-228 (1979).

68. Kaaber, K., Menne, T., Veien, N. K. \& Baadsgaard, O. Some adverse effects of disulfiram in the treatment of nickel-allergic patients. Derm. Beruf. Umwelt. 35, 209-211 (1987).

69. Itzhaki, R. F. et al. Microbes and Alzheimer's disease. J. Alzheimers Dis. 51, 979-984. https://doi.org/10.3233/JAD-160152 (2016).

70. Fulop, T. et al. Can an infection hypothesis explain the beta amyloid hypothesis of Alzheimer's disease?. Front. Aging Neurosci. 10, 224. https://doi.org/10.3389/fnagi.2018.00224 (2018).

71. Honjo, K., van Reekum, R. \& Verhoeff, N. P. L. G. Alzheimer's disease and infection: do infectious agents contribute to progression of Alzheimer's disease?. Alzheimers Dement. 5, 348-360 (2009).

72. Malaguarnera, M. et al. Helicobacter pylori and Alzheimer's disease: a possible link. Eur. J. Intern. Med. 15, 381-386 (2004).

73. Kountouras, J. et al. Five-year survival after Helicobacter pylori eradication in Alzheimer disease patients. Cogn. Behav. Neurol. 23, 199-204 (2010).

74. Zhan, X. et al. Gram-negative bacterial molecules associate with Alzheimer disease pathology. Neurology 87, 2324-2332 (2016).

75. Kumar, D. K. et al. Amyloid-beta peptide protects against microbial infection in mouse and worm models of Alzheimer's disease. Sci. Transl. Med. 8, 340-372. https://doi.org/10.1126/scitranslmed.aaf1059 (2016).

76. Ge, R., Sun, X., Wang, D., Zhou, Q. \& Sun, H. Histidine-rich protein Hpn from Helicobacter pylori forms amyloid-like fibrils in vitro and inhibits the proliferation of gastric epithelial AGS cells. Biochim. Biophys. Acta (BBA) Mol. Cell. Res. 1813, 1422-1427 (2011).

77. Ge, R. \& Sun, X. The in vivo functions of a histidine-rich protein Hpn in Helicobacter pylori: Linking gastric and Alzheimer's diseases together?. Med. Hypotheses 77, 788-790 (2011).

78. Moir, R. D., Lathe, R. \& Tanzi, R. E. The antimicrobial protection hypothesis of Alzheimer's disease. Alzheimers Dement. 14, $1602-1614(2018)$

\section{Acknowledgements}

This work was supported by the UGA Foundation (RJM). The authors declare that they have no conflict of interest. The authors acknowledge Kevin Clark (UGA Proteomics and Mass Spectrometry Facility) and John Glushka (UGA CCRC NMR facility) for their help with this project; Vincent Starai (UGA Microbiology) for the use of the Biotek Synergy 96-well microplate reader; Jorge Escalante and Elizabeth Villa (UGA Microbiology) for the use of the Nano-ITC. The in vitro or in vivo use of DMG to inhibit beta-amyloid aggregation and/or onset or progression of Alzheimer's disease is claimed under international patent application no. PCT/US2020/030483.

\section{Author contributions}

S.L.B and R.J.M. conceived the study, analyzed the data, wrote and reviewed the manuscript. S.L.B. performed all the experimental work.

\section{Competing interests}

The authors declare no competing interests.

\section{Additional information}

Supplementary Information The online version contains supplementary material available at https://doi.org/ 10.1038/s41598-021-86060-1.

Correspondence and requests for materials should be addressed to R.J.M.

Reprints and permissions information is available at www.nature.com/reprints.

Publisher's note Springer Nature remains neutral with regard to jurisdictional claims in published maps and institutional affiliations.

(c) (i) Open Access This article is licensed under a Creative Commons Attribution 4.0 International License, which permits use, sharing, adaptation, distribution and reproduction in any medium or format, as long as you give appropriate credit to the original author(s) and the source, provide a link to the Creative Commons licence, and indicate if changes were made. The images or other third party material in this article are included in the article's Creative Commons licence, unless indicated otherwise in a credit line to the material. If material is not included in the article's Creative Commons licence and your intended use is not permitted by statutory regulation or exceeds the permitted use, you will need to obtain permission directly from the copyright holder. To view a copy of this licence, visit http://creativecommons.org/licenses/by/4.0/.

(C) The Author(s) 2021 